\title{
Investment under Uncertainty with Strategic Debt Service*
}

\author{
Suresh Sundaresan ${ }^{\dagger}$ and Neng Wang ${ }^{\ddagger}$
}

December 28, 2006

The presence of a well designed bankruptcy code is an important part of the financial architecture in developed economies. By allowing the creditors to seize the assets of the borrowers who fail to make contractual payments, the code generates beneficial ex ante effects on debt capacity and firm value. By giving the borrowers options to renegotiate their debt obligations and seek bankruptcy protection, the code increases the likelihood that borrowers may avoid inefficient ex post liquidation. As Hart (1999) notes, the code should balance ex ante firm value maximization with ex post efficiency. The bankruptcy codes in different countries weight this tradeoff differently and hence vary in terms of the distribution of rights and powers between borrowers and lenders.

In this paper, we provide an inter-temporal framework to examine how the creditors' liquidation rights and the distribution of ex post bargaining powers influence the firm's investment and financing decisions, and affect ex ante firm value. We show that stronger equityholders' bargaining power lowers debt capacity, reduces firm value, and discourages growth option exercising. Our calibration suggests that the quantitative effects of ex post strategic renegotiation on ex ante firm value may be large.

Our paper provides an attempt to integrate financial architecture into the theory of investment (growth option exercising), by building on two strands of literature: investment and debt pricing. We extend the real options approach to investment, pioneered by McDonald and Siegel (1986) and Brennan and Schwartz (1985), to allow for capital structure decisions under strategic debt service. We also draw insights from corporate debt pricing/capital structure literature, which focuses on leverage and security pricing after investment has already been made (Merton (1974), Black and Cox (1976), and Leland (1994)). Our paper bridges the gap between these two strands of literature by characterizing the optimal investment and financing decisions, and the option value of waiting in closed form. We show that the interaction between financing and investment decisions in the presence of strategic debt service generates new insights and also quantitatively important effects on ex ante firm value.

\section{Model Setup and Solution}

We proceed in three steps. First, we set up the model. Second, we analyze the strategic renegotiation between equityholders and debtholders after debt is in place. Finally, we solve for the optimal investment decision and leverage decisions.

\footnotetext{
*Prepared for American Economic Review Papers \& Proceedings, 2007. We thank Patrick Bolton for helpful comments.

${ }^{\dagger} 811$ Uris Hall, Columbia University, 3022 Broadway, New York, NY 10027. Email: ms122@columbia.edu.

${ }^{\ddagger}$ Corresponding author. 812 Uris Hall, Columbia University, 3022 Broadway, New York, NY 10027. Email: nw2128@columbia.edu.
} 


\subsection{Model Setup}

The firm has one growth option and needs to decide when to exercise this growth option, how to finance the needed investment cost $I$, and how to engage in private workouts with creditors who have liquidation rights. We assume throughout the paper that the firm behaves in equityholders' interests. However, equityholders' incentives are different depending on whether debt has been issued or not. That is, they face a time inconsistency problem in their inter-temporal decisions, to be made precise later.

\section{Insert Figure 1 here.}

Figure 1 describes the decision making process of the firm over its life cycle. In each period, the firm (as a potential entrant) observes the market demand process $X$ for its good and decides if it should exercise its growth option to enter the market. Let the market demand shock $X$ be given by the following geometric Brownian motion (GBM) process:

$$
d X_{t}=\mu X_{t} d t+\sigma X_{t} d W_{t},
$$

where $W$ is a standard Brownian motion. Without losing key insights, we normalize the firm's output to be one unit and assume no variable cost of production. The process $X$ may also be viewed as the firm's earnings before interests and taxes (EBIT) process if the firm were in operation. Let $r>0$ denote the risk-free interest rate. Assume $r>\mu$ for convergence. To ensure that debt is not dominated by equity in our model, we follow the capital structure literature to assume that debt has tax benefits. Let the corporate tax rate be $\tau>0$. We ignore other taxes such as personal taxes for simplicity. Let $\Pi(x)$ denote after-tax all equity financed firm value (after the growth option is exercised). The standard valuation formula gives

$$
\Pi(x)=\left(\frac{1-\tau}{r-\mu}\right) x, \quad x \geq 0 .
$$

We will show that the firm's growth option exercising decision is characterized by a cutoff rule with endogenously determined threshold $x_{i}$. When the demand shock $X$ is below this endogenous threshold $x_{i}$, the firm waits to invest, as in the standard real options models. ${ }^{1}$ When the demand shock $X$ is at or above this endogenous threshold $x_{i}$, the firm exercises its growth option. The firm chooses a mixture of equity and (risky) debt to finance the fixed (constant) investment cost $I$ at endogenously chosen investment time $T_{i}$. The firm takes advantage of the tax benefits, but faces a conflict of interest between equityholders and debtholders after debt is in place (Myers (1977)). This conflict induced by equityholders' option to ex post walk away from their liabilities puts an upper bound on the firm's ex ante debt issuance. For analytical convenience, we follow Leland (1994) to assume that the risky debt issued at $T_{i}$ is perpetual.

After investing and issuing the risky debt at $T_{i}$, the firm collects the stochastic stream of EBIT $X$, meets its debt obligations, makes its tax payments, and distributes the remaining

\footnotetext{
${ }^{1}$ Dixit and Pindyck (1994) provide a standard textbook treatment on real options approach towards investment. Abel and Eberly (1994) develop a unified framework integrating the neoclassical adjustment cost literature with the literature on irreversible investment. The insights of this (real options) literature, which were developed in an all-equity financing framework, have been extended to settings with debt financing. Without exception, the extensions have relied on numerical procedures to draw out the relationship between optimal investment and financing decisions. See Mello and Parsons (1992), Hennessy and Whited (2005), and Pawlina (2005) for examples of research on investment with debt financing.
} 
proceeds to equityholders, in "normal" times (to be made precisely later). When $X$ is sufficiently low, equityholders may renege on the contractual debt payments and declare default at their chosen time. Upon equityholders' threatening to default, debtholders have an option to immediately liquidate the firm or renegotiate. However, liquidation may not necessarily be in debtholders' interests, if the firm is worth more under current (equityholders') management than under debtholders' management. Intuitively, there are gains to be realized and divided between equityholders and debtholders by renegotiation, when the firm as a going concern is worth more than its liquidation value. Empirically, we often see renegotiations between equityholders and debtholders when the firm is close to or in financial distress. Before discussing the details on how to model renegotiation, we first lay out the model's assumptions for payoffs when debtholders indeed liquidate the firm when equityholders threaten to default. The payoffs at liquidation for equityholders and debtholders will serve as natural reference points, not the equilibrium payoffs, for the bargaining game between them when debt is renegotiated.

We follow Leland (1994) to assume that the firm's liquidation value is $(1-\alpha) \Pi(x)$, a fraction $(1-\alpha)$ of the unlevered after-tax firm value $\Pi(x)$ given in (2). As in Leland (1994), we let $\alpha$ be exogenous and constant, and interpret $0 \leq \alpha<1$ as a measure of inefficiency due to liquidation. ${ }^{2}$ In Leland (1994), when equityholders do not make promised debt payments, debtholders will liquidate the firm and collect $(1-\alpha) \Pi(x)$ from liquidation. In our paper, when equityholders threaten to default, debtholders will renegotiate with equityholders the terms of the debt contract, as in Anderson and Sundaresan (1996), Mella-Barral and Perraudin (1997), and Fan and Sundaresan (2000).

The discussion in the proceeding paragraph suggests that equityholders may follow a cutoff policy, characterized by an endogenously chosen threshold $x_{s}$, when deciding to meet the contractual coupon payment or not. When $X$ falls below this endogenous threshold $\left(X<x_{s}\right)$, the firm may act strategically to negotiate a debt reduction with debtholders. When $X \geq x_{s}$, the firm collects EBIT $X$, meets its debt obligations, makes its tax payments, and distributes the remaining proceeds to equityholders. Let $E_{0}(x)$ denote firm (also equity) value before investment. The firm chooses the optimal investment policy (characterized by an endogenous investment threshold $x_{i}$ ) and coupon policy $c$ to maximize $E_{0}(x)$, anticipating the possible renegotiation in the future. Next, turn to the bargaining game between equityholders and debtholders.

\subsection{Bargaining between debtholders and equityholders}

When the firm does well, equityholders have no incentives to strategically renegotiate with debtholders. Intuitively, the threat to renegotiate is not credible, because debtholders can liquidate the firm and receive the residual firm value, which may be higher than the par value of debt. When the firm is not doing very well, firm value upon liquidation for debtholders may be lower than debt value under renegotiation. Under such a situation, equityholders may credibly threaten debtholders to default and hence may force a debt concession from debtholders. Liquidation is costly, however, it does not happen in equilibrium because of renegotiation. This differs from Leland (1994), where liquidation happens when equityholders choose to default.

\footnotetext{
${ }^{2}$ The particular linear payoff structure at default also implies that the firm loses tax shields from liquidation. The key intuition of our results does not hinge upon this particular parametric form for liquidation value.
} 
Let $V_{a}(x), E_{a}(x)$, and $D_{a}(x)$ denote firm value, equity value and debt value under the "normal" region, where EBIT $X$ is above the endogenous strategic debt service threshold $x_{s}$. Let $S(x)$ denote renegotiated debt coupon in the renegotiation region $\left(x<x_{s}\right)$. Note that we allow the renegotiated coupon $S(x)$ to vary with EBIT $x$. We assume that the tax advantage of debt is suspended when debt is renegotiated $\left(x<x_{s}\right)$. This assumption effectively treats debt in the renegotiation region as equity, and is more realistic in our model because $S(x)$ varies with EBIT $X$. Let $V_{b}(x), E_{b}(x)$, and $D_{b}(x)$ denote firm value, equity value, and debt value in the renegotiation region, respectively. Equityholders and debtholders negotiate and divide the surplus $\left(V_{b}(x)-(1-\alpha) \Pi(x)\right)$ from avoiding liquidation. The division of the surplus between equityholders and debtholders depends on their relative bargaining powers. Let $\eta$ and $(1-\eta)$ denote the respective equityholders' and debtholders' bargaining powers. The appendix provides definitions for various value functions in two regions.

Let $\theta_{e}(x)$ denote the fraction of firm value $V_{b}(x)$ that equityholders receive from renegotiation. Using Nash bargaining, we have that $\theta_{e}(x)$ solves

$$
\theta_{e}(x)=\arg \max _{\theta}\left(\theta V_{b}(x)\right)^{\eta}\left((1-\theta) V_{b}(x)-(1-\alpha) \Pi(x)\right)^{1-\eta} .
$$

Solving the above gives: $\theta_{e}(x)=\eta-\eta(1-\alpha) \Pi(x) / V_{b}(x)$. The sharing rule $\theta_{e}(x)$ implies that equity value and debt value in the renegotiation region are given by

$$
\begin{aligned}
E_{b}(x) & =\eta\left(V_{b}(x)-(1-\alpha) \Pi(x)\right) \\
D_{b}(x) & =(1-\alpha) \Pi(x)+(1-\eta)\left(V_{b}(x)-(1-\alpha) \Pi(x)\right) .
\end{aligned}
$$

The surplus created from not liquidating the firm and having the equityholders manage the firm is $\left(V_{b}(x)-(1-\alpha) \Pi(x)\right)$. Equity value in (4) is equal to the fraction of the surplus value obtained from avoiding liquidation, where the fraction is equal to the equityholders' bargaining power $\eta$. Debt value in (5) is given by debtholders' reservation value (liquidation value $(1-\alpha) \Pi(x))$ plus a second term, which is the product of the debtholders' bargaining power $(1-\eta)$ and the surplus value $\left(V_{b}(x)-(1-\alpha) \Pi(x)\right)$ from avoiding liquidation.

Solving the Nash bargaining game and using valuation equations, we obtain the following expression for the debt payment in the renegotiation region:

$$
S(x)=(1-\eta \alpha)(1-\tau) x, \quad x \leq x_{s} .
$$

The renegotiated debt payment $S(x)$ given in (6) states that debtholders give up the coupon claim $c$ and instead receive $(1-\eta \alpha)$ fraction of the firm's after-tax earnings in the renegotiation region $\left(x<x_{s}\right)$. Stronger bargaining powers for equityholders (higher $\eta$ ) lead to greater concessions to equityholders. A larger liquidation cost (higher $\alpha$ ) allows equityholders to extract more concessions from creditors, ceteris paribus. Debtholders effectively enter a debt-equity swap contract with existing equityholders whenever $x<x_{s}$. When $x \geq x_{s}$, the standard debt payment (constant coupon $c$ ) is in place. The specific tax treatment of the renegotiated debt payment is not crucial for our results. ${ }^{3}$

Next, we derive the threshold $x_{s}$ below which equityholders may negotiate with debtholders for a reduced coupon payment. To determine the threshold $x_{s}$, we need to uses equity values $E_{a}(x)$ and $E_{b}(x)$ in both the normal and renegotiation regions.

\footnotetext{
${ }^{3}$ The solutions will be modified if we treat the reduced payments to debtholders as tax deductible.
} 
Equity value in the normal region, $E_{a}(x)$, satisfies the following valuation equation:

$$
r E_{a}(x)=(1-\tau)(x-c)+\mu x E_{a}^{\prime}(x)+\frac{\sigma^{2}}{2} x^{2} E_{a}^{\prime \prime}(x), \quad x \geq x_{s} .
$$

Equityholders choose the threshold $x_{s}$ to maximize equity value. Intuitively, $E_{a}(x)$ and $E_{b}(x)$ are continuous and continuously differentiable at the threshold level $x_{s}$, in that

$$
\begin{aligned}
& E_{a}\left(x_{s}\right)=E_{b}\left(x_{s}\right), \\
& E_{a}^{\prime}\left(x_{s}\right)=E_{b}^{\prime}\left(x_{s}\right) .
\end{aligned}
$$

We obtain the following closed-form expression for the threshold $x_{s}$ in terms of coupon $c$ :

$$
x_{s}=\frac{1-\tau(1-\eta)}{1-\tau} \frac{1}{1-\eta \alpha}(r-\mu) \frac{\gamma}{\gamma-1} \frac{c}{r} .
$$

First, note that the renegotiation threshold $x_{s}$ (when $\eta=0$ and for a fixed coupon level $c$ ) is equal to $x_{\text {leland }}$, the default threshold in Leland (1994), where

$$
x_{\text {leland }}=(r-\mu) \frac{\gamma}{\gamma-1} \frac{c}{r} .
$$

While the thresholds are equal $(\eta=0)$, economic implications are different. Liquidation does not occur in our model, but does in Leland (1994). Second, the more bargaining power equityholders have (a higher $\eta$ ), the more surplus equityholders can extract from the debtholders. Hence, equityholders will renegotiate earlier (a higher $x_{s}$ ), ceteris paribus. Therefore, the endogenous threshold for debt renegotiation in our model is higher than the liquidation threshold in Leland (1994) for the same level of exogenously given $c$, in that

$$
\frac{x_{s}}{x_{\text {leland }}}=\frac{1-\tau(1-\eta)}{1-\tau} \frac{1}{1-\eta \alpha}>1, \quad \eta>0
$$

As the cost of inefficient liquidation $(\alpha)$ increases, the wedge between the debt renegotiation threshold $x_{s}$ and the Leland liquidation boundary $x_{\text {leland }}$ widens.

Now consider the firm's coupon decision. Because equityholders internalize tax benefits and agency costs of debt, the coupon payment $c$ is chosen to maximize firm value $V_{a}(x)$ given in (A.7). This gives

$$
c=\frac{r}{g}\left(\frac{1-\tau}{r-\mu}\right) \frac{\gamma-1}{\gamma} \frac{1-\eta \alpha}{1-\tau(1-\eta)} x,
$$

where $g>1$ is a constant and is given by

$$
g=\left[\frac{\beta}{\beta-\gamma}(1-\gamma)\right]^{-1 / \gamma} .
$$

Note that the optimal coupon is proportional to the EBIT value $x$. Typical credit risk/capital structure models such as Leland (1994) assume that financing takes place at time 0. That is, coupon given in (13) will be evaluated at the initial EBIT value $x_{0}$. We allow the financing decision to be made at the endogenously chosen time of investment $T_{i}$. We think that our model is best viewed as a financing model for growth option exercising. Next, we characterize the optimal real investment and the leverage decisions. 


\subsection{Optimal leverage and investment decisions}

Equityholders use a threshold policy to determine its growth option exercising decision, taking into account the financing and renegotiation decisions in the future. When EBIT $x$ is below the endogenous investment threshold $x_{i}$, firm (equity) value $E_{0}(x)$ satisfies the following valuation equation:

$$
r E_{0}(x)=\mu x E_{0}^{\prime}(x)+\frac{\sigma^{2}}{2} x^{2} E_{0}^{\prime \prime}(x), \quad x \leq x_{i} .
$$

Upon investing at time $T_{i}$, equityholders finance the investment cost $I$. Part of the financing comes out of debt issuance and the remaining is from equityholders. The total debt value raised at investment time $T_{i}$ is $D_{a}\left(x_{i}\right)$. Hence, the investment cost financed by equity is $I-D_{a}\left(x_{i}\right)$. The value matching condition at the time of investment is thus given by

$$
E_{0}\left(x_{i}\right)=E_{a}\left(x_{i}\right)-\left(I-D_{a}\left(x_{i}\right)\right)=V_{a}\left(x_{i}\right)-I .
$$

Because equityholders internalize the net benefits from debt issuance, the optimality condition for equityholders in choosing $x_{i}$ is the following "smooth pasting" condition:

$$
E_{0}^{\prime}\left(x_{i}\right)=V_{a}^{\prime}\left(x_{i}\right) .
$$

Firm is worthless if there is no demand at all times. This gives the absorbing barrier condition for ex ante firm value: $E_{0}(0)=0$. Firm value before investing, $E_{0}(x)$, is then given by

$$
E_{0}(x)=\left(\frac{x}{x_{i}}\right)^{\beta}\left(V_{a}\left(x_{i}\right)-I\right), \quad x \leq x_{i},
$$

where $V_{a}(x)$ is given in (A.7), and $\beta>1$ is given by (A.9).

Now, we derive closed-form solutions for the investment threshold $x_{i}$, the renegotiation threshold $x_{s}$, and optimal coupon $c$ jointly as functions of structural parameters in the model. In the next section, we use these solutions to deliver intuition behind the interactions between the investment and financing decisions.

Proposition 1 The firm's investment decision follows a stopping time rule $T_{i}=\inf \{t$ : $\left.X(t) \geq x_{i}\right\}$, where the investment threshold $x_{i}$ is given by

$$
x_{i}=\frac{\beta}{\beta-1}\left(\frac{r-\mu}{1-\tau}\right)\left(1+\tau \frac{1-\eta \alpha}{1-\tau(1-\eta)} \frac{1}{g}\right)^{-1} I .
$$

The coupon for debt (in the "normal" region $x \geq x_{s}$ ) is given by

$$
c=r \frac{\gamma-1}{\gamma} \frac{\beta}{\beta-1}\left(g \frac{1-\tau(1-\eta)}{1-\eta \alpha}+\tau\right)^{-1} I .
$$

Equityholders strategically renegotiate with debtholders, whenever $X(t) \leq x_{s}$, where $x_{s}$ is the endogenously determined strategic renegotiation threshold and is given by

$$
x_{s}=\frac{x_{i}}{g}=\frac{\beta}{\beta-1}\left(\frac{r-\mu}{1-\tau}\right)\left(g+\tau \frac{1-\eta \alpha}{1-\tau(1-\eta)}\right)^{-1} I .
$$

The reduced coupon payment is given by (6) in the "renegotiation" region $\left(x<x_{s}\right)$. Firm values $\left(V_{a}(x), V_{b}(x)\right)$, debt values $\left(D_{a}(x), D_{b}(x)\right)$, and equity values $\left(E_{a}(x), E_{b}(x)\right)$ are given in the appendix. The ex ante firm (equity) value $E_{0}(x)$ is given in (18). 
Note that the investment threshold $x_{i}$, the renegotiation threshold $x_{s}$, and the (contractual) coupon payment $c$ are all proportional to the growth option exercising cost $I$. These results are due to the GBM assumption for the EBIT process (1), perpetual debt, and perpetual renegotiation and investment options, among others. Note that the ratio between the investment threshold $x_{i}$ and the renegotiation threshold $x_{s}$ is constant and is larger than unity: $x_{i} / x_{s}=g>1$, where $g$ is given in (14). Moreover, the ratio $x_{i} / x_{s}=g$ is independent of the bargaining power $\eta$.

An important implication of Proposition 1 is that the inefficiency of costly liquidation (captured by $\alpha$ ) directly enters into the determination of the optimal investment threshold $x_{i}$, the optimal leverage $c$ and the debt concessions $(c-S(x))$, even though liquidation merely acts as a credible threat and does not occur in equilibrium.

\section{Model Analysis and Predictions}

Our model features the interaction between the investment and the financing decisions. Unlike the standard all equity-based real options models, the investment decision in our model is fundamentally tied to the financing friction induced by the strategic renegotiation between debtholders and equityholders in the future. Unlike Leland (1994) and other credit risk/contingent claim structural models, which are best viewed as models for financing of assets in place, our paper studies financing of growth option exercising.

The next proposition characterizes the properties of the optimal renegotiation threshold $x_{s}$, the coupon payment $c$, and the optimal investment threshold $x_{i}$ in our model with respect to equityholders' bargaining power $\eta$.

Proposition 2 Both the renegotiation threshold $x_{s}$ given in (21), and the optimal investment threshold $x_{i}$ given in (19) increase in equityholder's bargaining power $\eta$, in that $d x_{i} / d \eta>0$ and $d x_{s} / d \eta>0$. The optimal coupon payment $c$ given in (20) decreases in equityholders' bargaining power $\eta$, in that $d c / d \eta<0$.

When equityholders's bargaining power is stronger, equityholders can extract more out of the surplus from renegotiation, and debtholders anticipate higher reductions of the contractual coupon payments in the renegotiation region. This suggests that the renegotiation threshold $x_{s}$ increases with $\eta$. A higher renegotiation threshold $x_{s}$ lowers tax benefits ceteris paribus. This implies that debt capacity and the optimal coupon level $c$ decrease with equityholders' bargaining power $\eta$, ceteris paribus. Hence, incentives to invest decrease in $\eta$, and the firm waits longer before exercising its growth option (a higher threshold $x_{i}$ ), when $\eta$ is higher.

Next, we characterize the effects of equityholders' bargaining power (the value of $\eta$ ) on ex ante firm (equity) value $E_{0}(x)$, and compare with two natural benchmark settings: $(i)$ a benchmark (under all equity financing and $\tau=0$ ) and (ii) a setting under all equity financing with taxes $(\tau>0)$. The standard real options model (McDonald and Siegel (1986)) predicts that the optimal investment threshold (under all equity and $\tau=0$ ) is given by

$$
x_{i}^{*}=(r-\mu) \frac{\beta}{\beta-1} I,
$$

and the $e x$ ante firm value (in the waiting region) is given by $E_{0}^{*}(x)=\left(x / x_{i}^{*}\right)^{\beta}\left(x_{i}^{*} /(r-\mu)-I\right)$, 
for $x \leq x_{i}^{*}$. Under all equity financing and taxes, the investment threshold $x_{i}^{a e}$ is given by

$$
x_{i}^{a e}=\left(\frac{r-\mu}{1-\tau}\right) \frac{\beta}{\beta-1} I,
$$

and the ex ante firm value (in the waiting region) is $E_{0}^{a e}(x)=\left(x / x_{i}^{a e}\right)^{\beta}\left(\Pi\left(x_{i}^{a e}\right)-I\right)$, for $x \leq x_{i}^{a e}$. Taxes weaken the incentives of investment and lower equity values, in that $x_{i}^{a e}>x_{i}^{*}$ and $E_{0}^{a e}(x)<E_{0}^{*}(x)$, for all values of $x$. In the presence of taxes, issuing debt alleviates the investment distortions induced by taxes. Therefore, the investment threshold $x_{i}$ under equity/debt financing is lower than $x_{i}^{a e}$, in that $x_{i}<x_{i}^{a e}$. Moreover, firm value is higher under optimal financing than under equity financing $\left(E_{0}(x)>E_{0}^{a e}(x)\right.$, for all $\left.x\right)$. The next proposition summarizes the results on investment thresholds and firm values $E_{0}(x)$ under different financing arrangements.

Proposition 3 The investment threshold $x_{i}$ under optimal debt/equity financing satisfies the inequality: $x_{i}^{*}<x_{i}<x_{i}^{a e}$, where $x_{i}^{*}$ and $x_{i}^{a e}$ are given in (22) and (23), respectively. Payoffs at different times of exercising the growth option under all three settings are equal, in that

$$
\Pi\left(x_{i}^{a e}\right)=V_{a}\left(x_{i}\right)=\frac{x_{i}^{*}}{r-\mu}=\frac{\beta}{\beta-1} I .
$$

Finally, ex ante firm value $E_{0}(x)$ satisfies $E_{0}^{*}(x)>E_{0}(x)>E_{0}^{a e}(x)$, for all values of $x$.

\section{Insert Figure 2 here.}

Figure 2 plots ex ante firm value $E_{0}^{*}(x)$ under the benchmark setting (all equity financing and $\tau=0$ ), firm value $E_{0}(x)$ under (optimal) debt/equity financing (with $\eta=.5$ and $\tau>0$ ), and $E_{0}^{a e}(x)$ under all equity financing $(\tau>0)$. The horizonal line shows that the payoffs (at different endogenously chosen investment times) under all three settings are equal, confirming the results in Proposition 3. Our intuition relies on the following observation. First, the present discounted value of receiving a unit payoff contingent on hitting the investment threshold $x_{i}$ is $\Phi\left(x ; x_{i}\right)=\left(x / x_{i}\right)^{\beta}$ for $x<x_{i}$. It is immediate to see that $\Phi\left(p x ; p x_{i}\right)=\Phi\left(x ; x_{i}\right)$ for any constant $p>0$, provided that $X$ follows a GBM process (1). We may show that the gross payoffs upon exercising the growth option at any given candidate threshold level $x_{i}$ are equal to $p x_{i}$, proportional to $x_{i}$, under all three settings with different financing. Moreover, by optimally exercising the growth option, we may show that the optimal investment threshold is given by $p x_{i}=\beta I /(\beta-1)$. The net payoffs upon investment at different investment times under the three settings are thus all equal to $p x_{i}-I=I /(\beta-1)$. Because ex ante firm value is given by the product of $\Phi\left(x ; x_{i}\right)=\left(x / x_{i}\right)^{\beta}$ and the net payoffs $I /(\beta-1)$, we have the result that the ordering of the ex ante firm value $E_{0}(x)$ is determined by the ordering of $\left(1 / x_{i}\right)^{\beta}$. Figure 2 displays the ordering of the investment thresholds $x_{i}^{a e}>x_{i}>x_{i}^{*}$.

Next, we analyze the impact of strategic renegotiation (measured by the degree of equityholders' bargaining power $\eta$ ) on ex ante firm value $E_{0}(x)$ before its growth option is exercised. We compare the model's predictions with two previously constructed benchmark settings (under all equity financing): one without taxes and the other with $\tau>0$. Table 1 reports the effects of equityholders' bargaining power $\eta$ on ex ante firm value $E_{0}(x)$ scaled by firm values under comparison benchmark settings. Here, we choose the initial value $x_{0}$ 
to be in the waiting region $\left(x_{0} \leq x_{i}^{*}\right.$ where $x_{i}^{*}$ is given in (22)). The second row shows that taxes substantially lower firm value $E_{0}(x)$ by $17 \%$ to $39 \%$ of $E_{0}^{*}(x)$, the corresponding firm value under equity financing with $\tau=0$. The loss of firm value is greater when equityholders' bargaining power is stronger (a larger $\eta$ ). Intuitively, a higher bargaining power gives equityholders more incentives to engage in ex post opportunistic behavior and hence lowers ex ante debt capacity, and firm value more, ceteris paribus. The third row shows that firm value $E_{0}(x)$ is substantially higher than $E_{0}^{a e}(x)$, firm value under all equity financing and $\tau>0$. The gap between $E_{0}(x)$ and $E_{0}^{a e}(x)$ measures the net benefits of debt. When equityholders have no bargaining power, allowing the firm to choose its optimal leverage at the time of investment increases ex ante firm value by $89 \%$ ! There are two effects contributing to this magnitude of value increase. First, the investment threshold under $\eta=0$ is equal to $x_{i}=0.099$, about $80 \%$ of the all-equity investment threshold $x_{i}^{a e}=0.123$. Second, in order to convert the investment threshold ratio $x_{i} / x_{i}^{a e}$ into the value ratio, we need to compute the ratio $\Phi\left(x ; x_{i}\right) / \Phi\left(x ; x_{i}^{a e}\right)=\left(x_{i}^{a e} / x_{i}\right)^{\beta}$, where $\beta=2.86$ for this calibration. (We use Proposition 3 , which states the investment payoffs at different investment thresholds are equal across all settings under our analysis.) Intuitively, the option feature (captured by $\beta$ ) plays an important role in driving up the investment threshold difference about $20 \%$ to an ex ante firm value difference about $89 \%$.

To understand the effect of renegotiation on ex ante firm value $E_{0}(x)$, we now compare our model with the one-growth option setting, where renegotiation is ruled out, as in Sundaresan and Wang (2006). In that paper, the firm also chooses optimal capital structure to finance the growth option exercising, however, the firm makes its default decision as in Leland (1994) and hence costly liquidation occurs in equilibrium. The fourth row in Table 1 reports firm value $E_{0}(x)$ as a percentage of firm value $E_{0}^{l}(x)$ (without renegotiation) in Sundaresan and Wang (2006). While renegotiation increases firm value by avoiding costly ex post liquidation, renegotiation also induces a cost on ex ante firm value $E_{0}(x)$ from equityholders' ex post strategic renegotiation as discussed earlier.

When equityholders' bargaining power $\eta$ is low, firm value under renegotiation is higher than under costly liquidation. Intuitively, the benefit of avoiding costly liquidation outweighs equityholder's ex post opportunistic behavior. As a result, allowing equityholders to renegotiate with debtholders ex post enhances firm value. For example, firm value is increased by $29 \%$ by allowing for renegotiation, if equityholders have no bargaining power. However, when equityholders' bargaining power $\eta$ is high, ex ante firm value $E_{0}(x)$ under future renegotiation may be lower than ex ante firm value $E_{0}^{l}(x)$ under potentially costly liquidation as in Sundaresan and Wang (2006). Intuitively, the cost of equityholders' ex post opportunistic behavior dominates the benefit of avoiding costly liquidation. For example, when equityholders have all the bargaining power $(\eta=1)$, firm value $E_{0}(x)$ is $6 \%$ lower than firm value under costly liquidation, as seen from Table 1.

Finally, the remaining Table 1 confirms our comparative statics results reported in Proposition 2. The fifth and the six rows in Table 1 show that both the investment threshold $x_{i}$ and the renegotiation threshold $x_{s}$ increase with equityholders' bargaining power $\eta$. The last row shows that the coupon payment $c$ decreases with $\eta$. 


\section{Conclusions}

We have provided a parsimonious framework to model the role of financial architecture on $e x$ ante growth option exercising decisions and firm value when debt offers tax benefits. A key ingredient in our paper is the ex post bargaining and renegotiation between equityholders and debtholders. We show that stronger equityholders' bargaining power lowers debt capacity, reduces firm value, and delays growth option exercising.

There are two important extensions for future work. First, the framework can be used to model chapter 11 features of the bankruptcy code and the contingent transfer of control rights from borrowers to lenders when the firm files for chapter 11 . The other is to allow the firm to exercise multiple growth options sequentially over time. This extension will generate an integrated dynamic capital structure and investment decisions, not captured in the current paper. Sundaresan and Wang (2006) study the joint growth option exercising, capital structure, and default decisions for a firm endowed with sequentially ordered growth options. Unlike Sundaresan and Wang (2006) which models default as an equityholder's option and debtholders react passively, this paper and suggested future research focus on the effects of strategic debt service between equityholders and debtholders on the firm's growth option exercising decisions and ex ante firm value. 


\section{Appendices}

\section{A Proofs}

Proof of Proposition 1. Consider the setting after the growth option is exercised $\left(t \geq T_{i}\right)$. Debt value $D_{a}(x)$ and equity value $E_{a}(x)$ in the normal region $\left(x \geq x_{s}\right)$ are given by

$$
\begin{aligned}
& D_{a}(x)=\mathbb{E}_{t}^{x}\left[\int_{t}^{T_{s}} e^{-r(u-t)} c d u+e^{-r\left(T_{s}-t\right)} D_{b}\left(X\left(T_{s}\right)\right)\right], \\
& E_{a}(x)=\mathbb{E}_{t}^{x}\left[\int_{t}^{T_{s}} e^{-r(u-t)}(1-\tau)(X(u)-c) d u+e^{-r\left(T_{s}-t\right)} E_{b}\left(X\left(T_{s}\right)\right)\right],
\end{aligned}
$$

where deb value $D_{b}(x)$ and equity value $E_{b}(x)$ in the renegotiation region $\left(x \leq x_{s}\right)$ are respectively given by

$$
\begin{aligned}
D_{b}(x) & =\mathbb{E}_{t}^{x}\left[\int_{t}^{T_{s}} e^{-r(u-t)} S(u) d u+e^{-r\left(T_{s}-t\right)} D_{a}\left(X\left(T_{s}\right)\right)\right] \\
E_{b}(x) & =\mathbb{E}_{t}^{x}\left[\int_{t}^{T_{s}} e^{-r(u-t)}((1-\tau) X(u)-S(u)) d u+e^{-r\left(T_{s}-t\right)} E_{a}\left(X\left(T_{s}\right)\right)\right] .
\end{aligned}
$$

Let $V_{a}(x)$ and $V_{b}(x)$ denote firm values in the normal region and the renegotiation regions, respectively. We have $V_{a}(x)=E_{a}(x)+D_{a}(x)$ and $V_{b}(x)=E_{b}(x)+D_{b}(x)$.

By the standard valuation principle we have

$$
\begin{aligned}
& r V_{a}(x)=(1-\tau)(x-c)+c+\mu x V_{a}^{\prime}(x)+\frac{\sigma^{2}}{2} x^{2} V_{a}^{\prime \prime}(x), \quad x \geq x_{s}, \\
& r V_{b}(x)=(1-\tau) x+\mu x V_{b}^{\prime}(x)+\frac{\sigma^{2}}{2} x^{2} V_{b}^{\prime \prime}(x), \quad x \leq x_{s} .
\end{aligned}
$$

Using the boundary conditions (Dixit and Pindyck (1994)): $V_{a}\left(x_{s}\right)=V_{b}\left(x_{s}\right)$, and $V_{a}^{\prime}\left(x_{s}\right)=$ $V_{b}^{\prime}\left(x_{s}\right)$, we solve the differential equations (A.5-A.6) and obtain firm value functions:

$$
\begin{aligned}
& V_{a}(x)=\Pi(x)+\frac{\tau c}{r}-\frac{\tau c}{r} \frac{\beta}{\beta-\gamma}\left(\frac{x}{x_{s}}\right)^{\gamma}, \quad x \geq x_{s}, \\
& V_{b}(x)=\Pi(x)-\frac{\tau c}{r} \frac{\gamma}{\beta-\gamma}\left(\frac{x}{x_{s}}\right)^{\beta}, \quad x \leq x_{s},
\end{aligned}
$$

where $\beta$ and $\gamma$ are the positive and negative roots of the fundamental quadratic equations in the real options literature and are given by

$$
\begin{aligned}
& \beta=\frac{1}{\sigma^{2}}\left[-\left(\mu-\frac{\sigma^{2}}{2}\right)+\sqrt{\left(\mu-\frac{\sigma^{2}}{2}\right)^{2}+2 r \sigma^{2}}\right]>1, \\
& \gamma=-\frac{1}{\sigma^{2}}\left[\left(\mu-\frac{\sigma^{2}}{2}\right)+\sqrt{\left(\mu-\frac{\sigma^{2}}{2}\right)^{2}+2 r \sigma^{2}}\right]<0 .
\end{aligned}
$$


Using the renegotiated debt coupon $S(x)$, we note that equity value $E_{b}(x)$ satisfies the following valuation equation:

$$
r E_{b}(x)=(1-\tau) x-S(x)+\mu x E_{b}^{\prime}(x)+\frac{\sigma^{2}}{2} x^{2} E_{b}^{\prime \prime}(x), \quad x \leq x_{s}
$$

In order to ensure that renegotiated coupon $S(x)$ is always below the original coupon level $c$, we make the following parametric assumption:

$$
(1-\tau(1-\eta))\left(\frac{r-\mu}{r}\right) \frac{\gamma}{\gamma-1}<1 .
$$

Using the surplus sharing rules (4) and (5) for equity and debt, and firm value $V_{b}(x)$ given in (A.8), we have equity and debt values $E_{b}(x)$ and $D_{b}(x)$ in renegotiation regions:

$$
\begin{aligned}
& E_{b}(x)=\eta\left[\alpha \Pi(x)-\frac{\tau c}{r} \frac{\gamma}{\beta-\gamma}\left(\frac{x}{x_{s}}\right)^{\beta}\right], \quad x \leq x_{s}, \\
& D_{b}(x)=\left[(1-\eta \alpha) \Pi(x)-(1-\eta) \frac{\tau c}{r} \frac{\gamma}{\beta-\gamma}\left(\frac{x}{x_{s}}\right)^{\beta}\right], \quad x \leq x_{s} .
\end{aligned}
$$

Using the boundary conditions (8) and (9), and $V_{a}(x)$ in (A.7), we obtain closed-form formulae for equity value $E_{a}(x)$ and debt value $D_{a}(x)$ in the "normal" region $\left(x \geq x_{s}\right)$ :

$$
\begin{aligned}
& E_{a}(x)=\Pi(x)-\frac{(1-\tau) c}{r}-\left[(1-\eta \alpha) \Pi\left(x_{s}\right)-\frac{c}{r}\left(1-\tau-\tau \frac{\eta \gamma}{\beta-\gamma}\right)\right]\left(\frac{x}{x_{s}}\right)^{\gamma}, \\
& D_{a}(x)=\frac{c}{r}-\frac{c}{r}\left[\frac{1}{1-\gamma}+\frac{\gamma}{\gamma-1} \tau(\beta-1)(1-\eta) \frac{1}{\beta-\gamma}\right]\left(\frac{x}{x_{s}}\right)^{\gamma} .
\end{aligned}
$$

Finally, we maximize equity value $E_{0}(x)$ given in (18) with respect to $x$, evaluate at $x_{i}$, and obtain

$$
\beta\left(V_{a}\left(x_{i}\right)-I\right)=V_{a}^{\prime}\left(x_{i}\right) x_{i}
$$

Using (A.7) and evaluating $x_{s}$ given in (10) and coupon $c$ given in (13) at the moment of investment, we have

$$
(\beta-1)\left(\frac{1-\tau}{r-\mu}+\frac{\tau}{r} r\left(\frac{1-\tau}{r-\mu}\right) \frac{\gamma-1}{\gamma} \frac{1-\eta \alpha}{1-\tau(1-\eta)} \frac{1}{g} \frac{-\gamma}{1-\gamma}\right) x_{i}=\beta I .
$$

Simplifying gives the explicit formula for the investment threshold $x_{i}$ given in (19).

Proof of Proposition 2. The results immediately follow from Proposition 1.

Proof of Proposition 3. First, we show that as long as the (gross) payoff to equityholders when exercising the growth option at the threshold $x_{i}$ is proportional to $x_{i}$, then the payoff values when investing are identical and independent of financing arrangements. Suppose that the gross payoff when investing is given by $p x$, where $p>0$ is a constant.

Because the equity value $E_{0}(x)$ (for $x \leq x_{i}$ ) is given by product of $(i)$ the present discounted value of a unit payoff at the investment threshold $x_{i},\left(x / x_{i}\right)^{\beta}<1$, and $(i i)$ the net 
payoff at the investment threshold, $p x_{i}-I$. Therefore, equityholders choose $x_{i}$ to maximize $\left(x / x_{i}\right)^{\beta}\left(p x_{i}-I\right)$. Solving gives

$$
p x_{i}=\frac{\beta}{\beta-1} I
$$

Therefore, equity value is given by $\left(x / x_{i}\right)^{\beta} I /(\beta-1)$.

Now, we show that for both equity financing and optimal financing, we have linear payoff value. Under all equity financing with taxes, the gross payoff value when investing is given by $\Pi\left(x_{i}^{a e}\right)=(1-\tau) x_{i}^{a e} /(r-\mu)$. Under all equity financing without taxes, the gross payoff value when investing is given by $\Pi\left(x_{i}^{*}\right)=x_{i}^{*} /(r-\mu)$. Finally, under optimal financing, we have

$$
V_{a}\left(x_{i}\right)=\left(\frac{1-\tau}{r-\mu}+\frac{\tau}{r} r\left(\frac{1-\tau}{r-\mu}\right) \frac{\gamma-1}{\gamma} \frac{1-\eta \alpha}{1-\tau(1-\eta)} \frac{1}{g} \frac{-\gamma}{1-\gamma}\right) x_{i},
$$

using expressions for $g$ given in (14), and $c$ given in (20). 


\section{References}

Abel, Andrew, and Janice Eberly, (1994), "A unified model of investment under uncertainty," American Economic Review, 84, 1369-1384.

Anderson, Ronald and Suresh Sundaresan, (1996), "Design and Valuation of Debt Contracts", Review of Financial Studies, No. 9, pages 37-68.

Brennan, Michael J., and Eduardo S. Schwartz, (1985), "Evaluating natural resource investments," Journal of Business, 58, 135-57.

Black, Fisher, and John Cox, (1976), "Valuing corporate securities: Some effects of bond indenture provisions," Journal of Finance 81, 351-67.

Dixit, Avinash, and Robert S. Pindyck, (1994), Investment under Uncertainty, Princeton University Press.

Fan, Hua and Suresh Sundaresan (2000), "Debt Valuation, Renegotiation, and Optimal Dividend Policy", Review of Financial Studies, No. 13, pages 1057-1099.

Hart, Oliver, (1999), "Different Approaches to Bankruptcy," working paper, Harvard University.

Hart Oliver, and John Moore (1998), "Default and Renegotiation: A Dynamic Model of Debt," Quarterly Journal of Economics, 113, 1-41.

Hennessy, Christopher A. and Toni Whited, (2005), "Debt Dynamics," Journal of Finance, 60, 1129-65.

Leland, Hayne, (1994), "Corporate Debt Value, Bond Covenants, and Optimal Capital Structure," Journal of Finance, 49, pages 1213-1252.

McDonald, R., and D. Siegel, 1986, "The value of waiting to invest," Quarterly Journal of Economics 101, 707-728.

Mello, Antonio S., and John E. Parsons, (1992), "Measuring the Agency Cost of Debt," Journal of Finance, 47, pages 1887-1904.

Mella-Barral, Pierre and William Perraudin, (1997), "Strategic Debt Service," Journal of Finance, 52, pages 531-556.

Merton, Robert C., (1974), On the Pricing of Corporate Debt: The Risk Structure of Interest Rate, Journal of Finance 29, 449-69.

Myers, Stewart, (1977), "Determinants of corporate borrowing," Journal of Financial Economics, 5, 147-75.

Pawlina, Grzegorz, (2005), "Under-investment, Capital Structure and Strategic Debt Restructuring," working paper, Lancaster University.

Sundaresan, Suresh and Neng Wang (2006), "Investment under uncertainty with strategic debt service", working paper, Columbia University. 


\begin{tabular}{|c|cccccc|}
\hline$\eta$ & 0 & 0.2 & 0.4 & 0.6 & 0.8 & 1.0 \\
\hline$\frac{E_{0}\left(x_{0}\right)}{E_{0}^{*}\left(x_{0}\right)}-1$ & $-17 \%$ & $-23 \%$ & $-28 \%$ & $-32 \%$ & $-36 \%$ & $-39 \%$ \\
\hline$\frac{E_{0}\left(x_{0}\right)}{E_{0}^{a e}\left(x_{0}\right)}-1$ & $89 \%$ & $75 \%$ & $64 \%$ & $54 \%$ & $46 \%$ & $39 \%$ \\
\hline$\frac{E_{0}\left(x_{0}\right)}{E_{0}^{l}\left(x_{0}\right)}-1$ & & & & & & \\
\hline investment threshold $x_{i}$ & 0.099 & 0.101 & 0.103 & 0.106 & 0.108 & 0.110 \\
\hline renegotiation threshold $x_{s}$ & 0.073 & 0.075 & 0.077 & 0.079 & 0.080 & 0.082 \\
\hline & & $19 \%$ & $12 \%$ & $5 \%$ & $-1 \%$ & $-6 \%$ \\
\hline coupon $c$ & 0.113 & 0.101 & 0.090 & 0.080 & 0.070 & 0.061 \\
\hline
\end{tabular}

Table 1: The effects of bargaining power $\eta$ on firm value $E_{0}(x)$, compared with all equity based benchmark settings. This table reports $E_{i}\left(x_{0}\right)$ as a fraction of firm value under three comparison benchmarks: $(i)$ all equity without taxes; $(i i)$ all equity with taxes and (iii) optimal debt/equity financing without renegotiation (as in Leland (1994) and Sundaresan and Wang (2006)). We choose the initial value to be in the waiting region. For example, any $x_{0} \leq x_{i}^{*}$ works. Benchmark parameter values: $\alpha=35 \%, r=6 \%, \tau=25 \%$, $\mu=0, \sigma=15 \%$, and $I=1$. Under the benchmark with all equity financing and no taxes, the first-best investment threshold is 0.092. Under the benchmark with all equity financing and $\tau>0$, the investment threshold is 0.123 . 


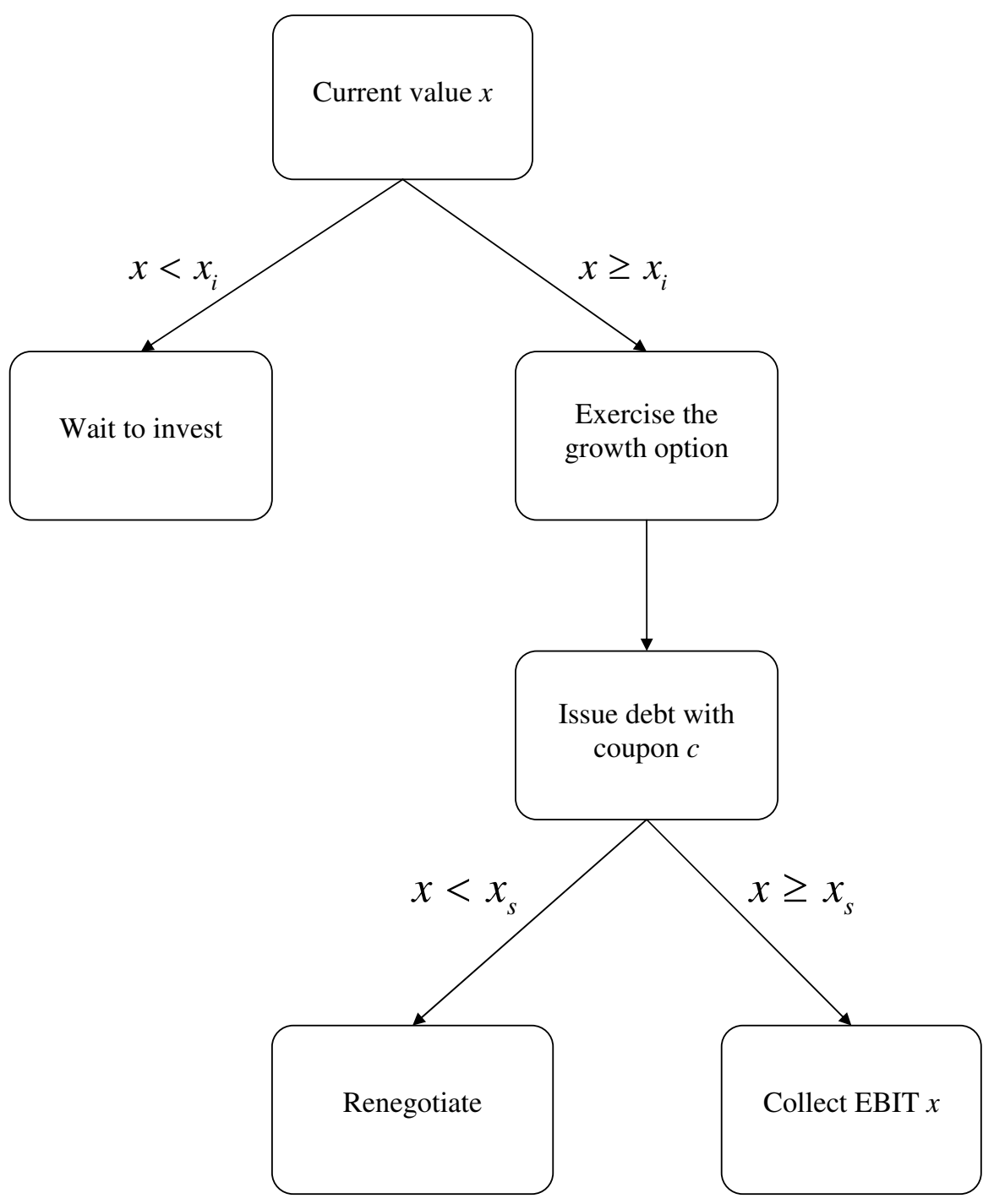

Figure 1: The firm's decision making process. The firm has one growth option. It exercises its first growth option when $x \geq x_{i}$ and waits otherwise. When exercising, the firm issues a mixture of equity and perpetual (risky) debt with coupon $c$ to finance the exercising cost $I$, and generates EBIT $x$. When $x \leq x_{s}$, the firm renegotiates with its debtholders and achieve a debt reduction from $c$ to $S(x)$ given in (6), and pays taxes to the government. When $x \geq x_{s}$, the firm pays its contractually agreed coupon payment and government taxes. 


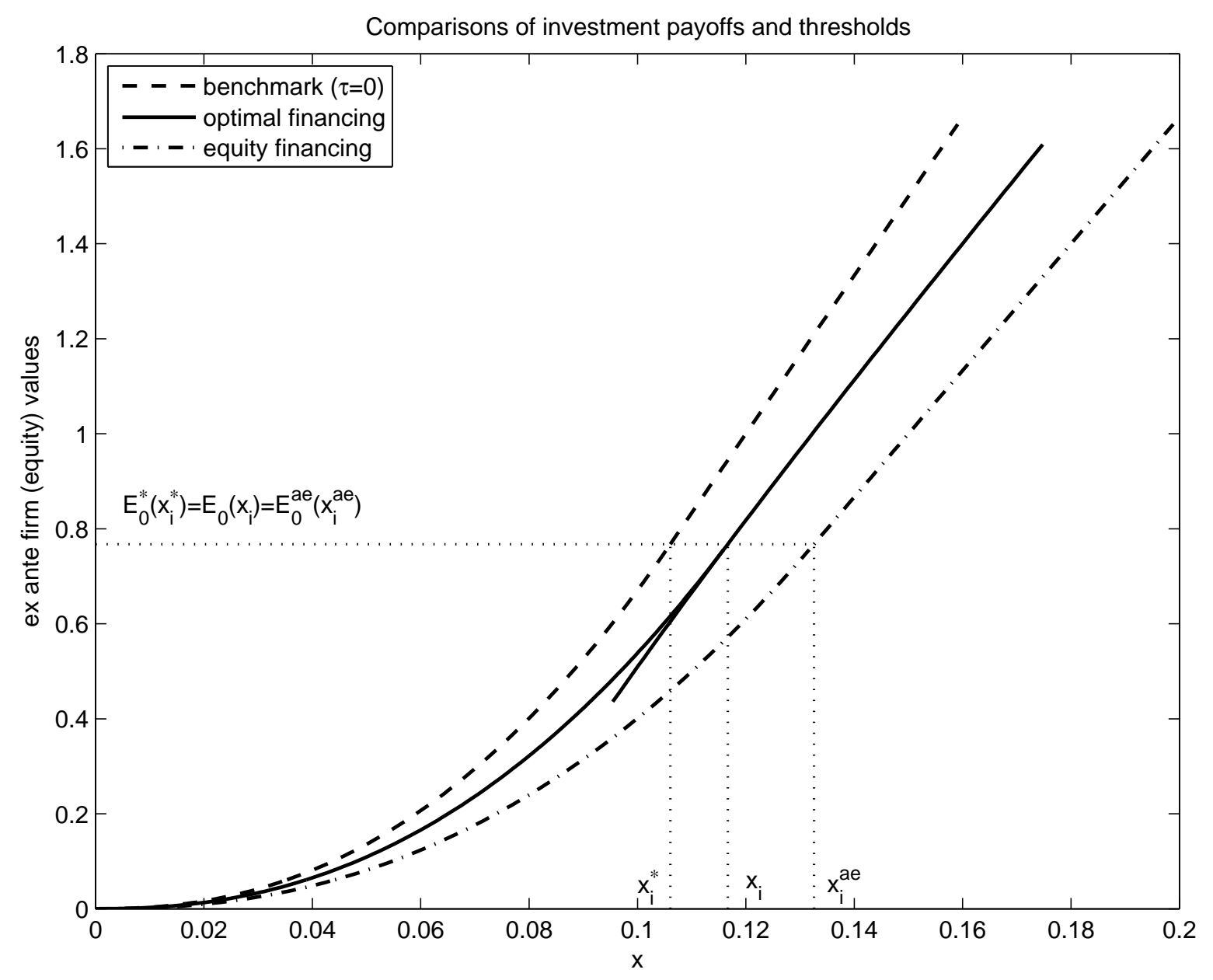

Figure 2: Equity values $E_{0}(x)$ and the investment thresholds under all equity financing (with $\tau=20 \%$ ), (optimal) debt financing (with $\eta=.5$ and $\tau=20 \%$ ), and all equity financing (with $\tau=0$ ). The respective investment thresholds are ordered sequentially: $x_{i}^{*}<x_{i}<x_{i}^{a e}$. Payoffs at (different) exercising thresholds are equal under the three settings, in that $x_{i}^{*} /(r-\mu)=V_{a}\left(x_{i}\right)=\Pi\left(x_{i}^{a e}\right)$, as seen from the horizontal dashed line. Equity value $E_{0}(x)$ under benchmark (with all equity financing and $\tau=0$ ) is highest; Equity value $E_{0}(x)$ under all equity financing (with $\tau>0$ ) is the lowest; Equity value $E_{0}(x)$ under (optimal) debt/equity financing lies between the two equity values under equity financing (with $\tau=0$ and with $\tau>0$ ). The (solid) concave curve $V_{a}(x)-I$ is the payoff under debt financing from exercising, where $V_{a}(x)$ is the firm value (in the normal region) after investing. Parameter values: $\alpha=35 \%, r=6 \%, \tau=20 \%, \mu=0, \sigma=20 \%$, and $I=1$. 